\title{
Influence of Problem Based Learning Model and Early Mathematics Ability to Mathematical Communication Skills and Self-Confidence in Junior High School
}

\author{
Muhammad Febri Rafli", Edi Syahputra, Yusnadi \\ Departement of Basic Education, Postgraduate School, State University of Medan, Indonesia \\ *Corresponding author: febrirafli@email.com \\ Received September 10, 2018; Revised October 30, 2018; Accepted November 23, 2018
}

\begin{abstract}
This study aims to determine: (1) the effect of problem based learning model on students mathematical communication skills, (2) the effect of problem based learning model on students self-confidence, (3) the interaction between learning models (problem based learning and conventional learning) and early mathematics ability to students mathematical communication skills, and (4) the interaction between learning models (problem based learning and conventional learning) and early mathematics ability to student's self-confidence. This study is a quasi-experimental research. The population in this study were all students of class VIII junior high school 2 Tanjung Pura consisting of six classes. Samples were selected by simple random sampling as much as two classes. The selected class is VIII-2 as the experimental class (31 students) and VIII-1 as the control class (32 students). The instruments used are mathematical communication skills test, early mathematics ability test, self-confidence questionnaire. Data obtained from the research instruments were analyzed using two-way ANOVA by SPSS program. The results showed that: (1) there is significant effect of problem based learning model to students mathematical communication skill, (2) there is a significant effect of problem based learning model to students self-confidence, (3) there is interaction between learning models (problem based learning and conventional learning) and early mathematics ability to students' mathematical communication skills, (4) there is interaction between learning models (problem based learning and conventional learning) and early mathematics ability to student's self-confidence.
\end{abstract}

Keywords: problem based learning, mathematical communication ability, self-confidence, early mathematics ability

Cite This Article: Muhammad Febri Rafli, and Edi Syahputra, Yusnadi, "Influence of Problem Based Learning Model and Early Mathematics Ability to Mathematical Communication Skills and Self-Confidence in Junior High School." American Journal of Educational Research, vol. 6, no. 11 (2018): 1539-1545. doi: 10.12691/education-6-11-12.

\section{Introduction}

In general mathematics has five objectives in mathematics learning. These objectives include: developing mathematical attitudes, gaining proficiency in the use of mathematical language, gaining insight into applications from mathematics in other disciplines [1]. One of the goals of mathematics learning has a purpose so students can communicate well. This is in accordance with the standard of the mathematics learning process formulated by the National Council of Teacher of Mathematics [2], namely: 1) mathematical problem solving, 2) mathematical reasoning, 3) mathematical communication, 4) mathematical connections, and 5) mathematical representation. Learn most of the communication and construct their own knowledge. In addition, with communication students can improve vocabulary, develop speaking skills, write ideas systematically and have better learning abilities $[3,4]$. Mathematical communication has an important role for students in formulating mathematical concepts and strategies, investing students in the completion of exploration and mathematical investigation, and means for students to communicate to obtain information, share ideas and findings $[5,6]$. However, the results of the study show that many students experience difficulties in mathematics. Arifin, Kartono, and Sutarto [7] that students' mathematical communication skills are still low. Students have difficulty identifying and conveying ideas contained in a problem [8].

Learning objectives are also seen from the affective domain. In this case one of the affective domains that students need to have in mathematics learning is students' self-confidence attitude. Self-confidence can be interpreted as one part of feelings and thoughts about who we really are [9]. In relation to mathematics learning, self-confidence can be built by erasing the impression that mathematics lessons place students as objects by accepting the theory and memorizing formulas. The ease in learning mathematics can make students appreciate and love mathematics 
$[10,11]$. From the results of other studies indicate that there is an influence between students 'confidence in students' mathematics learning outcomes $[12,13]$. In fact, students still have problems with confidence. Students always complain that they have no ability, especially in learning mathematics. When learning, students easily give up and complain that learning is difficult. If asked to work on a question in front of the class, students are overly afraid and feel uncertain about the answer [10,14].

More specifically, the low mathematical communication skills and self-confidence of students cannot be separated from the teacher's view of the meaning and model of learning. This is in accordance with what was revealed by Slameto [15] that the role of teachers in the teaching and learning process is to encourage, guide, and provide learning facilities for students to achieve goals. One learning model that can be used to answer these problems is a problem based learning model. Rusman [16] suggests that problem based learning is useful to facilitate the success of problem solving, communication, group work and interpersonal skills better than other approaches. The results show that problem-based learning is effective to improve students' mathematical communication skills. When problem solving is used as a context in mathematics, the focus of learning activities is entirely on students, namely the process to understand a mathematical concept and procedure contained in the problem [17,18]. Amalia, Surya, and Syahputra [19] says that in the use of problem based learning, students were guided to find their own answers by following the steps of the PBL model. As in other studies problem based learning makes students more creative, dare to make decisions, think rationally and collaborate effectively with their classmates [20].

The success of students in taking mathematics lessons is also very influential on the early mathematical ability factor. Akramunnisa and Sulestry [21] revealed in the learning process, the teacher must pay attention to the students' early mathematical abilities in solving mathematical problems, because the mathematical concepts that are related to each other and form new concepts that are more complex. By knowing the early ability of each student's mathematics, the teacher will be easier in determining the method or strategy suitable for use in the classroom so that the learning carried out will be more effective and efficient [22]. The expected end result, the problem based learning model can stimulate students to be more confident both in terms of communication verbally and in writing because each student always interacts between the teacher and other students. This is reinforced by the results of research which revealed that students who have high confidence in mathematics will easily answer mathematical communication problems [23].

\section{Literature Review}

\subsection{Mathematical Communication Skills}

Fiske [24] also states that communication as social interaction through messages and all communication involves signs and codes. Effendy [25] the communication process is essentially a process of delivering thoughts or feelings by a person (communicator) to others (communicant). The mind can be in the form of ideas, information, opinions, and others that emerge from his mind. Baroody [26] says that education should help children to communicate mathematical ideas with the representation, listening, reading, discussion and writing. Communication through mathematics, teachers can foster student engagement and participation while focusing on a deep conceptual understanding has been mentioned in the general standard of mathematics. Development the language of mathematics to note for the students to better understand mathematical concepts underlying [27]. Yusra and Saragih [28] says that the mathematical communication skills is the ability to disclosure of mathematical ideas with symbols, tables, diagrams, or other media to clarify the issue of mathematics and delivered with a mathematical language in teaching and learning mathematics in the learning process of mathematics.

In this research study, mathematical communication skills of junior high school (SMP) has been expressed by Manitoba Education [29] that the communication in mathematics students daily delivery either orally, through diagrams and pictures, and writing about mathematics. Students need opportunities to read, present, view, write, listen, and discuss mathematical ideas. It is almost similar is said by NCTM [30] that the communication in mathematics for secondary level there are a few things to note are (1) related to mathematical ideas, (2) access some answers solution method, (3) allows multiple presentation of diverse, and (4) a chance in the interpretation, and hypothesizing. Mathematical communication skills Junior high school students are measured from four aspect, namely: 1) convert mathematical situations or ideas into drawing, 2) formulate mathematical ideas into language and mathematical symbols, 3) chage information from an image/table into mathematical language and symbols, and, 4) explain procedures settlement.

\subsection{Self-Confidence}

Self-confidence is a positive mental attitude from a person individuals who position or condition themselves to be able to evaluate themselves and their environment so that they fell comfortable doing activities in an effort achieve planned goals [31,32]. Brewer and Barlow [33] also suggest that self-confidence is closely related to ability and knowledge in a particular domain and is influenced by the amount of information taken, the clarity and details of the target. As well as the influence of the domain of knowledge, self-confidence is also influenced by students' beliefs about, awareness of themselves, general abilities in learning and strategy. Similar to this, Pierce and Stacey [34] defines mathematical beliefs, as students' perceptions of their ability to achieve good results and their assurance that they can handle difficulties in mathematics. Margono [35] divides ones's confidence in mathematics into three components, namely as follows: 1) trust in understanding and self-awareness regarding mathematical abilities, 2) ability to realistically determine the goals to be achieved and develop an action plan as an effort to achieve the intended goals, and 3) trust in mathematics itself. 


\subsection{Early Mathematics Ability}

According to Rusman [16] knowledge of students' early abilities is important for teachers to be able to provide the right portion of the lesson and it is useful to take the necessary steps. Early mathematical abilities describe the readiness of students in doing mathematics learning activities. Another thing explained by Astuti [36] is that initial knowledge is a framework in which students filter new information and find meaning about what is being learned in the learning process. Russeffendi [37] states that from a group of students who are randomly selected (not specifically chosen) there are always a number of children with high, moderate and low ability who are normally distributed. The student's initial mathematical abilities are important to know before he starts with his learning, because it can be known whether students already have or knowledge that is a prerequisite for learning. The extent to which students have known what material will be presented. By knowing this, the teacher will be able to design learning better. Because if students are given material that is already known, they will feel bored quickly. Classification of students' initial knowledge consists of groups consisting of smart groups, moderate and less [38]. Akramunnisa and Sulestry [21] reveal the initial ability of mathematics is the level of students' ability to solve existing mathematical problems its relationship with the material underlying these questions. The students' initial mathematical abilities that vary greatly influence the achievement of the next mathematics learning outcomes.

\subsection{Model Problem Based Learning}

Problem based learning is learning that optimizes students' thinking skills through a systematic process of group work or teams, so students can empower, sharpen, test, and develop their thinking skills in a sustainable manner [16]. Problem based learning will encourage students to think divergently. Divergent thought patterns will lead them to the formation of creativity. Learning by giving problems that contain many solutions or many ways of solving can improve students' mathematical creativity [39]. Problem based learning has an effect on content knowledge which provides greater opportunities for students to learn with more involvement and increase student active participation, motivation and interest among students. This causes students to have a positive attitude towards mathematics and help them to improve their performance for the most part and which will cause long-term memory [26].

Problem Based Learning is an effective approach to high level thinking. This learning helps students to process the information that has been formed in their minds and compiles their own knowledge about the social world and its surroundings. In this study the stages of the problem based learning model are: 1) Giving problems to students; 2) Reviewing the problem given; 3) Guiding individual and group mastery; 4) Develop and present the work; and 5) Analyze and evaluate the problem solving process. By using problem based learning that is able to develop inquiry and problem solving as well as collaborative, communicative, cooperative learning and learning processes, self-direction can be influenced by students' mathematical communication skills and self-confidence. From the various issues above, the problems that will be discussed in this study are:

1. Is there an effect of problem based learning model on students' mathematical communication skills?

2. Is there an effect of problem based learning model on student self-confidence?

3. Are there interactions between the learning model and early mathematical abilities towards students' mathematical communication skills?

4. Are there interactions between the learning model and the students early mathematical abilities towards students' self-confidence?

\section{Methods}

The type of research used in this study is quasi-experimental. This research was conducted at junior high school 2 Tanjung Pura. The population in this study were all eighth grade students. While sample selection is done by cluster random sampling technique. The sample in this study was class, VIII-2 which was used as an experimental class with total 31 students and class VIII-1 was used as a control group totaling 32 students. This study involved two classes treated differently. The experimental group is treated by applying the problem based learning model, while the control group is treated by applying conventional learning. The instruments used are mathematical communication skills test consists of 4 essay, early mathematics ability test amounted to 6 essay, self-confidence questionnaire of 33 statements. Data obtained from research instruments were analyzed using two-way ANOVA through the SPSS program.

\section{Result}

\subsection{Findings}

Initial description presented is the result of test early mathematical ability is given to know the average equality experimental class and control class. This test is also conducted to group students, namely high, medium, and low. The results of the summary presented in Table 1. below.

Table 1. Description of Students' Early Mathematical Abilities Based on Learning Models

\begin{tabular}{ccc}
\hline \multirow{2}{*}{ Statistic } & \multicolumn{2}{c}{ Learning } \\
\cline { 2 - 3 } & Problem Based Learning & Conventional Learning \\
\hline $\mathrm{N}$ & 31 & 32 \\
\hline Mean & 73,26 & 71,7 \\
\hline $\begin{array}{c}\text { Standar } \\
\text { Deviation }\end{array}$ & 7,43 & 6,04 \\
\hline
\end{tabular}

Table 1. gives a conclusion that the average score of the early mathematical abilities for each sample class is relatively the same. For the problem based learning class obtained 73.26 while the conventional learning class was obtained 71.7. So if there is a difference in the results of students' abilities in each sample class is caused by different treatments, not because there are differences before learning. Next, the results of the calculation of mathematical communication skills and self-confidence of students can be seen in the following Table 2: 
Table 2. Mean and Standard Deviation KKM Test and Self-Confidence Questionary on PBL class and CL class

\begin{tabular}{lcccc}
\hline \multirow{2}{*}{ Class } & \multicolumn{2}{c}{ KKM Test } & \multicolumn{2}{c}{ Self-Confidence Questionary } \\
\cline { 2 - 5 } & Mean & Standar Deviation & Mean & Standar Deviation \\
\hline Problem Based Learning & 76,63 & 11,44 & 72,24 & 6,78 \\
\hline Coventional Learning & 69,34 & 12,91 & 6,18 & \\
\hline
\end{tabular}

Table 3. ANAVA Test of Mathematical Communication Skill

\begin{tabular}{lccccc}
\hline Source & Type III Sum of Squares & Df & Mean Square & F & Sig. \\
\hline KAM & 2485,944 & 2 & 1242,972 & 12,182 & 7,000 \\
\hline Pembelajaran & 728,651 & 1 & 728,651 & \\
\hline KAM* Pembelajaran & 672,952 & 2 & 336,476 & 0,010 & 3,298 \\
\hline
\end{tabular}

Table 4. Self-Confidence ANAVA Test

\begin{tabular}{|c|c|c|c|c|c|}
\hline Source & Type III Sum of Squares & Df & Mean Square & $\mathrm{F}$ & Sig. \\
\hline KAM & 602,736 & 2 & 301,368 & 10,373 & 0,000 \\
\hline Pembelajaran & 148,521 & 1 & 148,521 & 5,112 & 0,028 \\
\hline KAM * Pembelajaran & 205,936 & 2 & 102,968 & 3,544 & 0,035 \\
\hline
\end{tabular}

In Table 1, it can be seen the average mathematical communication skills and self-confidence of the two groups of students who are taught with the problem based learning and conventional learning models. The problem based learning model obtained an average mathematical communication ability of 76.63, while students who received regular learning obtained an average mathematical communication skills of 69.34. While the problem based learning model obtained an average self-confidence of 72.24, while students who received conventional learning gained an average self-confidence of 68.18. To determine the significance of the data in statistical testing with a two-way anava test, it was previously tested for data normality and homogeneity. The results of homogeneity and normality of the two classes from the tests of mathematical communication skills and self-confidence questionnaire indicated that the two sample groups had homogeneous variance and normal data distribution. The following are the results of the two-way anava calculation of mathematical communication skills presented in Table 3, namely.

Based on the results of a two-way ANOVA in Table 3 above, the p-value was obtained for the study was $0,010<0,05$, that is enough evidence to reject $\mathrm{H}_{0}$ and accept $\mathrm{H}_{1}$. Means that there is influence of problem based learning models on students' mathematical communication skills. In other words the influence of the problem based learning model on mathematical communication skills is better than conventional learning on mathematical communication skills. In the interaction of learning models (problem based learning and conventional learning) with early mathematical ability obtained $p$-value $=0.044<0.05$ or in other words enough evidence to reject $\mathrm{H}_{0}$, thus significantly there is an influence of interaction between learning (problem based learning and conventional) with the early ability of mathematics towards students' mathematical communication skills. The following are the results of the two-way analysis of students' self-confidence in those presented in Table 4, namely.

Based on the results of the two-way ANOVA test in Table 4 above, the p-value was obtained for the study was $0.028<0.05$, that is enough evidence to reject $\mathrm{H}_{0}$ and accept $\mathrm{H}_{1}$. It means that there is the influence of the problem based learning model on students' self-confidence.
In other words, the effect of the problem based learning model on self-confidence is better than conventional learning about self-confidence. In the interaction of learning models (problem based learning and conventional) with early mathematical abilities obtained $p$-value $=0.035$ $<0.05$ or in other words enough evidence to reject $\mathrm{H}_{0}$, thus significantly there is an influence of interaction between learning (problem based learning and conventional learning) with early mathematical abilities towards student self-confidence.

\subsection{Discussions}

The research findings reveal that the average value of students 'mathematical communication skills taught with the problem based learning model is higher than the average value of students' mathematical communication skills taught by conventional learning. This proves that the problem based learning model is better than the usual learning done by the teacher in developing students' mathematical communication skills. The results of previous studies explain that mathematical communication skills in the experimental class (model problem based learning) is better than conventional learning by teachers $[41,42,43,44]$.

Surya, Syahputra, and Juniati [43] during the process of PBL lead to interaction between students and teachers to learn is often the case, it will eventually make students brainstorm and to reflect the understanding that he had before. Khun-Inkeeree, Omar-Fauzee, and Othman [45] revealed confidence built by the ability to interact in the classroom. This is probably because the module or student activity sheet used in classroom interaction that creates opportunities for students to interact freely during class activities. The learning process is presented by the model problem based learning not only to transfer knowledge from teacher to student, but a process that is conditioned by the teacher so that students are active in a variety of ways to build his own knowledge. Kadir and Parman [46] gives a contextual problem students' attention and challenge students to solve it by means of a mathematical method or communicate their mathematical ideas. Kodariyati and Astuti [36] describes in more visible model of problem based learning students actively in 
learning. In a study using problem based learning models, communication skills can be developed in the form of questions at the beginning of learning. The use of student worksheets given to each group also influences the course of the learning process.

The study's findings prove that the use of problem-based student activity sheet structured nature of the inquiry was able to grow in the early mathematical concepts. With the activity sheet, students have no difficulty in answering math problems. students simply follow the patterns that have been provided in the sheet. It tersebur accordance with Kodariyati and Astuti [42] In a study using problem based learning models, communication skills can be developed in the form of questions at the beginning of learning. In addition, the presence of a class discussion makes the students are encouraged to bring an idea or ideas. Use of worksheets that are given to each group also influences the course of the learning process. Astriani, Surya, and Syahputra [47] explains when students are working on the student worksheet and test math skills through contextual problems would encourage students in learning activities to help each other, sharing, respect between the different learning abilities possessed by each student.

The above explanation is supported by learning theory that supports the mathematical communication skills contained in Runtukahu [48] the symbolic stage in the theory of child development from Bruner states that children manipulate symbols or symbols of certain objects. Students are able to use notation without relying on real objects. Other cognitive theories from Piaget say cognitive development as a child process actively builds systems of meaning and understanding of reality through their experiences and interactions [49]. The study's findings also support previous research thatNurbaiti, Irawati and Lichteria [44] found that the model of problem based learning and expository able to jointly provide a positive influence on students' mathematical communication skills. Other results also indicate the interaction between early ability learning model mathematics to students' mathematical ability [50,51]. Problem based learning to students' attitudes that students use problem-based learning show a positive attitude in dealing with problems that are superior because of the element of interaction and constructivism were very prominent in problem-based learning [52].

The findings also showed that the average value of the self-confidence of students who are taught by a model problem based learning is higher than the average value of the self-confidence of students who are taught by conventional learning. This proved that the model of problem based learning is better than the usual lesson by the teacher in developing students' self-confidence. Results of previous studies also showed that the attitude of self-confidence of students who are taught by a model problem based learning is better than the expository $[53,54,55]$. Nurqolbiah [52] the self-confidence of students who are built through problem-based learning with a scientific approach is superior in showing a positive attitude in dealing with problems.

Self-confidence can also be developed by doing rational and realistic learning in the student environment. This is in line with the problem based learning model which begins to present mathematical problems for students, so students are required to solve problems that are rich in mathematical concepts [56]. Previous research by Cerezo [57] suggests that student responses are very positive by liking problem-based learning. Students are able to work in groups. Students feel problem-based learning makes them challenged to think differently, be open to new ideas and not judgmental, and to be supportive of each other. Rokhmawati, Djatmika, and Wardana [58] the application of PBL models can also improve students' positive attitudes. This shows that students have developed skills to adapt to the environment and can have self-control. This can be seen from the courage of students appearing to give opinions, the ability to think positively, and the confidence to communicate in class.

Finally, this study shows that students who have the initial ability of high and moderate mathematics are more benefited than students who have low initial math skills. This means that the problem based learning model is well used for students who have high and moderate categories of early mathematical abilities in developing students' mathematical communication skills and self-confidence. Darkasyi, Johar, and Ahmad [59] explain learning models that enable students to improve students 'mathematical communication skills in terms of students' early mathematical abilities (low, medium, high). Utami and Misnasanti [60] if students can use the early knowledge well in understanding new material, it will affect the ability to solve mathematical problems. Students will be able to solve the problems faced by linking the knowledge they have with new knowledge.

\section{Conclusion}

Based on the research described in the previous section, can be summed up as follows:

1. Mathematical communication ability of students taught using problem based learning models better than taught using conventional learning.

2. The attitude of self-confidence of students showed better results in the classroom with a model of problem based learning than classroom with conventional learning. This study shows that there are positive effects of problem based learning model with self-confidence of students.

3 . There is an interaction between learning models (problem based learning and conventional learning) and early ability of mathematics to students' mathematical communication skills.

4. There is an interaction between learning models (problem based learning and conventional learning) and early ability of mathematics to students' selfconfidence.

\section{Suggestions for Future Studies}

From the findings obtained by feeding can be given to the next researcher who develops the learning model, first, the researcher can develop the learning components used in the problem-based learning model and computer-based model development. Second, before giving a learning model, the researcher should further examine students 'and 
teachers' perceptions of the learning model provided. So that students and teachers really understand the learning model use.

\section{Acknowledgements}

The author would like to thank who have helped write this simple journal. I am really thankful to them.

\section{References}

[1] Heuvel-Panhuizen, M. V. d. and Wijers, M. "Mathematics standards and curricula in the Netherlands," Journal ZDM, 37 (4). 287-307. 2005.

[2] CSSU Math Curriculum Committe, CSSU Math Frameworks, NCTM, Reston, 2004.

[3] Ramellan, P., Musdi, E. and Armiati, "Kemampuan Komunikasi Matematis Dan Pembelajaran Interaktif," Jurnal Pendidikan Matematika, 1 (1). 77-82. 2012

[4] Tandililing, E, "The Enhancement of Mathematical Communication and Self Regulated Learning of Senior High School Students through PQ4R Strategy Accompanied by Refutation Text Reading. International Seminar and the Fourth National Conference on Mathematics Education Department of Mathematics Education, Yogyakarta State University, 917-928.

[5] Saragih, S. and Rahmiyana, "Peningkatan Kemampuan Komunikasi Matematis Siswa SMA/MA di Kecamatan Simpang Ulim Melalui Model Pembelajaran Kooperatif TIPE STAD," Jurnal Pendidikan dan Kebudayaan, 19 (2). 174-188. 2013.

[6] Kurnia, R.N., Setiawani, S. and Kristiana, A.I, "Analisis Kemampuan Komunikasi Matematis Siswa Kelas VII C SMP Negeri 1 Rogojampi Tahun Pelajaran 2014/2015," Artikel Ilmiah Mahasiswa, 1 (1). 1-6. 2015.

[7] Arifin, A.T., Kartono, and Sutarto, H, "Keefektifan Strategi Pembelajaran React Pada Kemampuan Siswa Kelas VII Aspek Komunikasi Matematis," Jurnal Kreano, 5 (1). 91-98. 2014

[8] Agustyaningrum, A, "Implementasi Model Pembelajaran Learning Cycle $5 E$ Untuk Meningkatkan Kemampuan Komunikasi Matematis Siswa Kelas IX- B SMP Negeri 2 Sleman," Seminar Nasional Matematika dan Pendidikan Matematika, Yogyakarta, Desember 2011.

[9] Srimadevi, T. and Saraladevi, K, "Decision Making And Self Confidence On Problem Solving Ability Among Higher Secondary Student Studying Mathematics," International Journal Of Innovative Research In Science, Engineering And Technology, 5 (3). 3509-3514. 2016

[10] Hendriana, H, "Membangun Kepercayaan Diri Siswa Melalui Pembelajaran Matematika Humanis," Jurnal Pengajaran MIPA, 19 (1). 52-60. 2014.

[11] Martyanti, A, "Membangun Self-Confidence Siswa Dalam Pembelajaran Matematika Dengan Pendekatan Problem Solving," Seminar Nasional Matematika dan Pendidikan Matematika, FMIPA UNY Yogyakarta, 15-22.

[12] Ameliah, I.H., Munawaroh, M. and Muchyidin, A, "Pengaruh Keingintahuan Dan Rasa Percaya Diri Siswa Terhadap Hasil Belajar Matematika Kelas VII MTs Negeri I Kota Cirebon," Jurnal EduMa, 5 (1). 9-21. 2016

[13] Hannula, M.S., Maijala, H. and Pehkonen, E, "Development of Understanding and Self Confidence in Mathematics; Grades 5-8," The 28th Conference of the International Group of the Psychology of Mathematics Education, 17-24.

[14] Nurdin, M, "Pengaruh Metode Discovery Learning untuk Meningkatkan Representasi Matematis dan Percaya Diri Siswa," Jurnal Pendidikan Universitas Garut, 9 (1). 9-22. 2016.

[15] Slameto, Belajar Dan Faktor-Faktor Yang Mempengaruhi, PT Rineka Cipta, Bandung, 2010.

[16] Rusman, Model-Model Pembelajaran Mengembangkan Profesionalisme Guru, PT. Raja grafindo Persada, Jakarta, 2014

[17] Fachrurazi, "Penerapan Pembelajaran Berbasis Masalah Untuk Meningkatkan Kemampuan Berpikir Kritis Dan Komunikasi Matematis Siswa Sekolah Dasar," Jurnal Edisi Khusus, 1. 76-89. 2011.
[18] Gijbels, D., Dochy, F., Bossche, P.V.d. and Segers, M, "Effects of Problem-Based Learning: A Meta-Analysis from the Angle of Assessment," Review of Educational Research, 75 (1). 27-61. 2005.

[19] Amalia, E., Surya, E. and Syahputra, E, "The Effectiveness Of Using Problem Based Learning (PBL) In Mathematics Problem Solving Ability For Junior High School Students," International Journal Of Advance Research And Innovative Ideas In Education, 3 (2). 3402-3406. 2017.

[20] Fatade, A.O., Mogari, D. and Arigbabu, A.A, "Effect of Problem-Based Learning On Senior Secondary School Student' Achievements In Further Mathematics," Acta Didactica Napocensia, 6 (3). 27-44. 2013.

[21] Akramunnisa and Sulestry, A.I, "Analisis Kemampuan Menyelesaikan Masalah Matematika ditinjau dari Kemampuan Awal Tinggi dan Gaya Kognitif Field Dependent (FI)," Jurnal Pedagogy, 1 (2). 46-56. 2016.

[22] Fatimah, A. E, "Peningkatan Kemampuan Pemecahan Masalah Matematis Dan Kemandirian Belajar Siswa SMK Negeri 1 Percut Sei Tuan melalui Pendekatan Differentiated Instruction," MES (Journal of Mathematics Education and Science), 2 (1). 11-23. 2016.

[23] Sidik, A., Ramlah. and Utami, M.R, "Hubungan Antara Self-Confidence dengan Kemampuan Komunikasi Matematis Siswa SMP," Prosiding Seminar Nasional Matematika dan Pendidikan Matematika, 222-226.

[24] Fiske, J, Pengantar Ilmu Komunikasi, PT. Raja Grafindo persada, Jakarta, 2014

[25] Effendy, O.U, Ilmu Komunikasi Teori dan Praktek, PT. Remaja Rosdakarya, Bandung, 2009

[26] Baroody, A.J, "Problem Solving, Reasoning, And Communicating, Macmillan Publishing Company, USA, 1993.

[27] Pourdavood, R.G. and Wachira, P, "Importance of Mathematical Communication and Discourse in Secondary Classrooms," Global Journals Inc, 15 (10). 9-20. 2015.

[28] Yusra, D.A. and Saragih, S, "The Profile of Communication Mathematics and Students' Motivation by Joyful Learning-based Learning Context Malay Culture," British Journal of Education, Society \& Behavioural Science, 15 (4). 1-16. 2016.

[29] Manitoba, Grade 8 Mathematics Support Document for Teachers, Manitoba Education and Advanced Learning, Canada, 2015.

[30] NCTM, Principles and Standards for School Mathematics, NCTM, Reston, 2000.

[31] Suhendri, H, "Pengaruh Kecerdasan Matematis-Logis, Rasa Percaya Diri, Dan Kemandirian Belajar Terhadap Hasil Belajar Matematika," Seminar Nasional Matematika dan Pendidikan Matematika, Universitas Negeri Yogyakarta, 397-404.

[32] Das, S.K., Halder, U.K. and Bairagya, S, "A Study on Selfconfidence vs. Mathematics Anxiety in Rural Teenager Students, International Journal of Informative \& Futuristic Research, 1 (9). 50-54. 2014.

[33] Brewer, W.C.S. and M. Barlow, "Confidence and accuracy in the recall of deceptive and nondeceptive sentences," Journal of Memory and Language, 52 (4). 618-627. 2005.

[34] Pierce, R. and Stacey, K, "A framework for monitoring progress and planning teaching towards the effective use of computer algebra systems," International Journal of Computers for Mathematical Learning 9. 59-93. 2004.

[35] Margono, G, "Pengembangan Instrumen Pengukur Rasa Percaya Diri Mahapeserta didik terhadap Matematika," Jurnal Ilmu Pendidikan, 12(1). 2005.

[36] Astuti, S.P, "Pengaruh Kemampuan awal dan minat belajar terhadap prestasi belajar Fisika," Jurnal Formatif, 5 (1). 68-75. 2015.

[37] Russefendi, H.E.T, Pengantar Kepada Membantu Guru Mengembangkan Kompetensinya Dalam pengajaran Matematika Untuk Meningkatkan CBSA, Tarsito, Bandung, 2006.

[38] Armanto, D, "Teaching and Learning Multiplication of Multi-Digit Numbers In Realistic Mathematics Education (RME)," Jurnal Pendidikan Matematika, 1 (1). 14-23. 2008.

[39] Syahputra, E, "Pembelajaran Berbasis Masalah dan Kreativitas Siswa dalam Pendidikan Matematika. Seminar Nasional Matematika Dan Terapan (SiManTap 2013), 453-459.

[40] Padmavathy, R.D. and Mareesh.K, "Effectiveness of Problem Based Learning in Mathematics," International Multidisciplinary e-Journal, 2 (1). 45-51. 2013.

[41] Sari, L.S.P. and Rahadi, M, "Pembelajaran Berbasis Masalah Untuk Meningkatkan Kemampuan Komunikasi Matematika Siswa 
Sekolah Menengah Pertama," Jurnal Pendidikan Matematika, 3 (3). 143-150. 2014

[42] Kodariyati, L. and Astuti, B, "Pengaruh Model PBL Terhadap Kemampuan Komunikasi Dan Pemecahan Masalah Matematika Siswa Kelas V SD,” Jurnal Prima Edukasia, 4 (1). 93-106. 2016.

[43] Surya, E., Syahputra, E. and Juniati, N, "Effect of Problem Based Learning Toward Mathematical Communication Ability and SelfRegulated Learning," Journal of Education and Practice, 9 (6): 14-23. 2018.

[44] Nurbaiti, S.I., Irawati, R. and Lichteria P,R, "Pengaruh Pendekatan Problem Based Learning Terhadap Kemampuan Komunikasi Matematis Dan Motivasi Belajar Siswa," Jurnal Pena Ilmiah, 1 (1). 1001-1010. 2016.

[45] Khun-Inkeeree, H., Omar-Fauzee, M.S., and Othman, M.K.H. The Effect of Students Confidence Level toward Mathematics Performance among Southern Thailand Primary School Children," International Journal of Academic Research in Progressive Education and Development, 6 (2). 20-34. 2017.

[46] Kadir, J. and Parman, M.S, "Mathematical Communication Skills of Junior Secondary School Students in Coastal Area," Jurnal Teknologi (Social Sciences), 63 (2). 77-83. 2013.

[47] Astriani, N., Surya, E. and Syahputra, E, "The Effect Of Problem Based Learning To Students' Mathematical Problem Solving Ability," International Journal Of Advance Research And Innovative Ideas In Education, 3 (2). 3441-3446. 2017.

[48] Runtukahu, J.T, Pembelajaran Matematika Dasar Bagi Anak Berkesulitan Belajar, Ar-Ruzz Media, Jogjakarta, 2014.

[49] Trianto, Mendesain Model Pembelajaran Inovatif-Progresif, Kencana, Jakarta, 2009.

[50] Effendi, L.A, "Pembelajaran Matematika Dengan Metode Penemuan Terbimbing Untuk Meningkatkan Kemampuan Representasi Dan Pemecahan Masalah Matematis Siswa SMP," Jurnal Penelitian Pendidikan, 13 (2). 1-10. 2012.

[51] Masri, M.F., Suyono. and Deniyanti, P, "Pengaruh Metode Pembelajaran Berbasis Masalah Terhadap Self-Efficacy Dan Kemampuan Pemecahan Masalah Matematis Ditinjau Dari Kemampuan Awal Matematika Siswa SMA," JPPM, 11 (1). 116126. 2018.
[52] Nurqolbiah, S, "Peningkatan Kemampuan Pemecahan Masalah, Berpikir Kreatif dan Self-Confidence Siswa Melalui Model Pembelajaran Berbasis Masalah," Jurnal Penelitian Pendidikan dan Pengajaran Matematika, 2 (2). 143-158. 2016.

[53] Surya, E., Putri, F.A., and Mukhtar, "Improving Mathematical Problem-Solving Ability and Self-Confidence of High School Students through Contextual Learning Model," Journal on Mathematics Education, 8 (1), 85-94. 2017.

[54] Purwasih, R, "Peningkatan Kemampuan Pemahaman Matematis dan Self-Confidence Siswa MTs di Kota Cimahi Melalui Model Pembelajaran Inkuiri Terbimbing," Jurnal Ilmiah STKIP Siliwangi Bandung DIDAKTIK, 9 (1). 16-25. 2015.

[55] Istiawati, S.N., Mulyono., and Syahputra, E, "The Effect of Based Learning Problem Model with Macromedia Flash to the Representation Mathematical Ability VII Grade Students of SMPN 1 Sidamanik," Journal of Education and Practice, 8 (23): 127-132. 2017.

[56] Widyatiningtyas, R., Kusumah, Y.S., Sumarmo, U. and Sabandar, J, "The Impact of Problem-Based Learning Approach to Senior High School Students' Mathematics Critical Thinking Ability," IndoMS-Journal Mathematics Education, 6 (2). 30-38. 2015.

[57] Cerezo, N, "Problem-Based Learning in the Middle School: A Research Case Study of the Perceptions of At-Risk Females," Research in Middle Level Education, 27 (1). 1-13. 2004.

[58] Rokhmawati, J.D., Djatmika, E.T. and Wardana, L, "Implementation of Problem Based Learning Model to Improve Students' Problem Solving Skill and Self-Efficacy (A Study on IX Class Students of Smp Muhammadiyah)," IOSR Journal of Research \& Method in Education (IOSR-JRME), 6 (3). 51-55. 2016.

[59] Darkasyi, M., Johar, R. and Ahmad, A, "Peningkatan Kemampuan Komunikasi Matematis dan Motivasi Siswa dengan Pembelajaran Pendekatan Quantum Learning pada Siswa SMP Negeri 5 Lhokseumawe," Jurnal Didaktik Matematika, 1 (1). 21-34. 2014.

[60] Utami, R.W. and Misnasanti, "Pengetahuan Awal terhadap Kemampuan Pemecahan Masalah Matematika Siswa," Seminar Matematika dan Pendidikan Matematika, Universitas Negeri Yogyakarta, 7-12. 